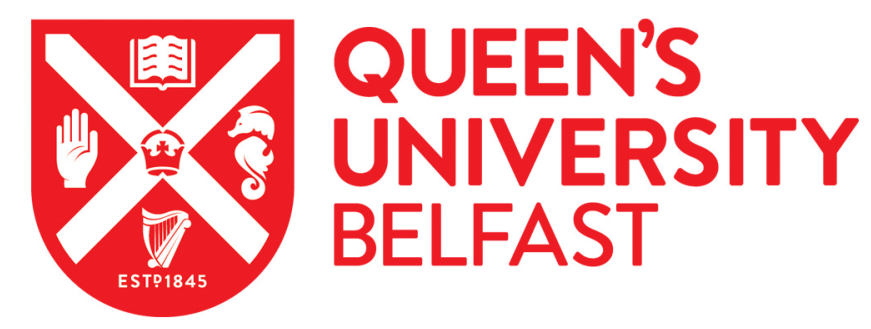

\title{
Synergistic effects of angiotensin converting enzyme and angiotensin II type 1 receptor gene polymorphisms on risk of myocardial infarction
}

Tiret, L., Bonnardeaux, A., Poirier, O., Ricard, S., Marques Vidal, P., Evans, A., Arveiler, D., Luc, G., Kee, F., Ducimetiere, P., Soubrier, F., \& Cambien, F. (1994). Synergistic effects of angiotensin converting enzyme and angiotensin II type 1 receptor gene polymorphisms on risk of myocardial infarction. Lancet, 344, 910-913.

Published in:

Lancet

Queen's University Belfast - Research Portal:

Link to publication record in Queen's University Belfast Research Portal

\section{General rights}

Copyright for the publications made accessible via the Queen's University Belfast Research Portal is retained by the author(s) and / or other copyright owners and it is a condition of accessing these publications that users recognise and abide by the legal requirements associated with these rights.

Take down policy

The Research Portal is Queen's institutional repository that provides access to Queen's research output. Every effort has been made to ensure that content in the Research Portal does not infringe any person's rights, or applicable UK laws. If you discover content in the Research Portal that you believe breaches copyright or violates any law, please contact openaccess@qub.ac.uk. 


\section{Synergistic effects of angiotensin-converting enzyme and angiotensin-II type 1 receptor gene polymorphisms on risk of myocardial infarction}

Laurence Tiret, Alain Bonnardeaux, Odette Poirier, Sylvain Ricard, Pedro Marques-Vidal, Alun Evans, Dominique Arveiler, Gérald Luc, Frank Kee, Pierre Ducimetière, Florent Soubrier, François. Cambien

\section{Summary}

We reported from our previous multicentre case-control study that the deletion (D) polymorphism of the gene encoding angiotensin-converting enzyme (ACE) was associated with increased risk of myocardial infarction. The main function of ACE is to convert angiotensin I into angiotensin 11 , which exerts its known cellular actions through the angiotensin II $A T_{1}$ receptor subtype $\left(A G T_{1} R\right.$ ). We have now investigated the role of a common polymorphism of the $A T_{1}$ receptor gene (an $A \rightarrow C$ transversion at position 1166 of $A G T_{1} R$ ) and looked for an interaction between $A C E$ and $A G T_{1} R$ gene polymorphisms on the risk of myocardial infarction.

We analysed DNA from 613 patients with myocardial infarction and 723 age-matched population controls. We found a significant interaction between $A C E$ and $A G T_{1} R$ gene polymorphisms; the odds ratio for myocardial infarction associated with the ACE $D D$ genotype was 1.05 (95\% $\mathrm{Cl} 0.75-1.49)$ for subjects without the $A G T_{1} R \quad C$ allele, $1.52(1.06-2.18)$ in $A C$ heterozygotes, and 3.95 $(1.26-12.4)$ in $C C$ homozygotes (test for trend, $p<0.02$ ). Among patients defined as low risk by traditional risk factors (serum apolipoprotein $B<1.25 \mathrm{~g} / \mathrm{L}$, body-mass index $<26 \mathrm{~kg} / \mathrm{m}^{2}$ ) the interaction was even stronger (odds ratios 1.64 [0.68-3.92], 7.03 [2.61-19.0], and 13.3 $[p=0.05]$, respectively).

These findings, if confirmed, could have clinical implications for the prevention and treatment of coronary heart disease.

Lancet 1994; 344: 910-13

See Commentary page 901

\section{Introduction}

The findings of the ECTIM (Etude Cas-Témoin I'Infarctus du Myocarde) multicentre study suggested tha a deletion (D) polymorphism in the gene encodin angiotensin-converting enzyme (ACE) is a risk factor fo myocardial infarction. ${ }^{1,2}$ Since those reports: some othe studies ${ }^{3-8}$ have confirmed involvement of the ACE polymorphism in the predisposition to coronary hear disease; yet others have not. ${ }^{9,10}$ The frequency of the $A C B$ $D D$ genotype is increased in the presence of lef ventricular hypertrophy" and dilated and hypertrophit cardiomyopathy, ${ }^{12,13}$ whereas high plasma concentrations of ACE are associated with carotid-wall thickening. ${ }^{14}$

The ACE $D D$ genotype is associated with raise circulating ${ }^{15}$ and cellular ${ }^{16}$ concentrations of ACE. The ACE I/D polymorphism is probably a neutral marker in tight linkage to a functional variant yet to be identified:i: $\mathrm{ACE}$ has a key role in the renin-angiotensin system, bi converting angiotensin I to angiotensin II; the lattet peptide has various effects including vasoconstriction, aldosterone production, and enhanced noradrenaline release from sympathetic nerve endings. ${ }^{18}$ Angiotensin also has hypertrophic, and possibly hyperplastic, effects on vascular smooth muscle cells and cardiomyocytes, and increases extracellular collagen matrix synthesis. 19,20

The cellular effects of angiotensin II are mediated by two structurally distinct receptor subtypes, $\mathrm{AT}_{1}$ and $\mathrm{AT}_{2}{ }^{21}$ Most of the known actions of angiotensin II are exerted through the $A T_{1}$ receptor, which is present in particular in vascular smooth muscle cells and in the myocardium. ${ }^{22}$ The CDNA encoding human AT receptor, a G-protein-coupled receptor, has been cloned. We have identified a polymorphism in the $3^{\prime}$ untranslated region of the $A G T, R$ gene, corresponding to an $A+C$ transversion at nucleotide position 1166 of the mRNi sequence. ${ }^{24}$

The physiological role of the $\mathrm{AT}_{1}$ receptor suggested that the AGT, R gene could be a candidate gene for myocardial infarction, possibly interacting with the ACE IID polymorphism. We investigated this hypothesis in the ECTIM study, a case-control study comparing men who survived myocardial infarction with appropriate controls: recruited from different European populations. ${ }^{25}$

\section{Patients and methods}

The populations who took part in the ECTIM study have been described. ${ }^{25}$ Patients with myocardial infarction were recrifired between 1989 and 1991 from the registers of the WHO/Multinational Monitoring of Trends and Determinants it Cardiovascular Disease (MONICA) in Belfast (Northering Ireland), Lille (northern France), Strasbourg (eastern France, and Toulouse (southwestern France). Men aged 25-64 years who survived a definite myocardial infarction (MONIG
INSERM U258 (L Tiret PhD, P Ducimetière PhD); INSERM U36 (A Bonnardeaux.MD, F Soubrier MD); INSERM SC7 (O Poirier PhD, S Ricard MSc, F Cambien MD), 17 rue du Fer à Moulin, 75005 Paris, France; and MONICA Project in Haute-Garonne, France (P Marques-Vidal MD), Belfast, UK (A Evans MD, F Kee MD), Bas-Rhin (D Arveiler MD), and Lille, France ( $G$ Luc MD)

Correspondence to: Dr François Cambien 
THE LANCET

\begin{tabular}{ll}
\hline \multicolumn{1}{l}{ Belfast } & \\
\hline Cases & Controls \\
98 & 85 \\
88 & 81 \\
15 & 14 \\
\hline
\end{tabular}

\begin{tabular}{|c|c|}
\hline \multicolumn{2}{|l|}{ Lille } \\
\hline & Controls \\
\hline 30 & $64 *$ \\
\hline 31 & 75 \\
\hline 4 & 9 \\
\hline
\end{tabular}

\begin{tabular}{|c|c|}
\hline \\
\hline \multicolumn{2}{|c|}{$\frac{\text { Strasbourg }}{\text { Cases }}$} \\
\hline \multirow{2}{*}{$\begin{array}{c}86^{*} \\
103\end{array}$} & 104 \\
\hline & 73 \\
\hline 14 & 12 \\
\hline
\end{tabular}

\begin{tabular}{|c|c|}
\hline \multicolumn{2}{|c|}{ Toulouse } \\
\hline Cases & Controls \\
\hline 69 & 102 \\
\hline 64 & 90 \\
\hline 11 & 14 \\
\hline
\end{tabular}

\begin{tabular}{|c|c|}
\hline All subjects & \\
\hline Cases & Controls \\
\hline 283 & 355 \\
\hline 286 & 319 \\
\hline 44 & 49 \\
\hline $0.69 / 0.31$ & $0.71 / 0.29$ \\
\hline
\end{tabular}

$A / C$

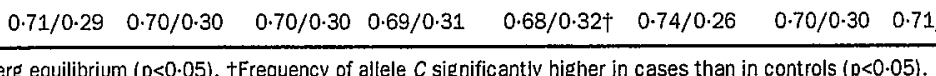

Significantideviation from Hardy-Weinberg equilibrium ( $p<0.05)$. $\uparrow$ Frequency of allele $C$ signific antly higher in cases than
Distributions of $A_{\text {GT }} R$ genotypes in cases and controls in four subpopulations

1) were recruited 3-9 months after the infarction. Agematched controls were obtained from the electoral rolls in France if from the lists of general practitioners held by the Central services Agency in Northern Ireland. To increase ethnic tomogeneity; we required that families of patients and controls

Mhomogen resident in the region for at least two generations and
ahd been

Thom
thad been resident in the region for at least two generations and
that all-four grandparents had been born in Europe or in Ulster. gene encoding

a risk factor rts, some ofthim : the ACE

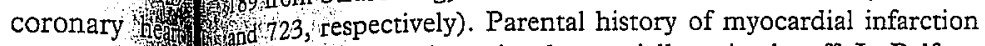

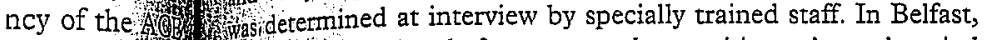

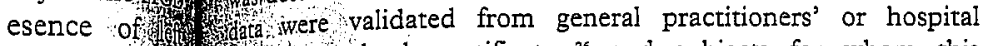
d hypertroph concentration was not possible (15\%) were excluded from the concentration ¿d with ta of $\mathrm{ACE}, \mathrm{m}$, W be identifiede isin system ${ }^{2}$ theatment with hypolipidaemic drugs who had plasma II; the latum

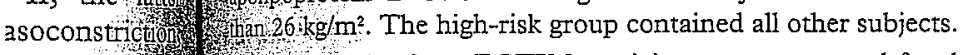

noradrendlind Angiotensing rplastic, effest

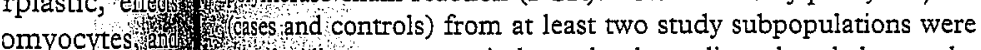
hesis. ${ }^{19,20}, 3$ pes, $\mathrm{AT}_{\mathrm{i}}$. giotensin 7 is presenth :lls and hin

human s been clones 3' untrans 1 a (x)

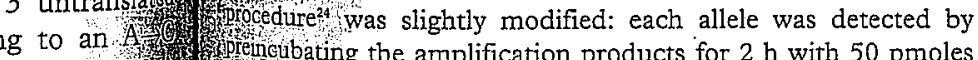
of the mRA Homplification products for $2 \mathrm{~h}$ with 50 pmoles of the mRN Why

pto
ida
wi

with the

ppothesis 110 aring men ipriate conte ons. ${ }^{25}$

All assays were independently replicated and the results tetalls. We developed a new assay to analyse degraded $\mathrm{DNA}_{3}{ }^{3}$ Wand replication of a subsample of the ECTIM study with this thew assay showed no discrepancy. The $A_{1} T_{1} A^{1166} \rightarrow C$ 7. Wh

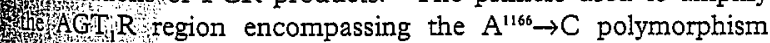

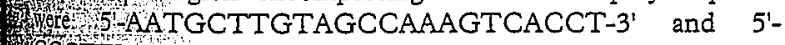

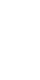

study have 2 were reg gisters of Deterninants Ifast Nojtien eastern Erang yed $25-64$ 位e :ion $(\mathrm{MON}$ of unlabelled oligonucleotide probe specific for the other allele and then incubating for $4 \mathrm{~h}$ with 10 pmoles of labelled probe specific for the allele (sequences published previousily ${ }^{24}$ ); the Inembranes were then washed and autoradiographed.

Statistical analyses were based on the calculation of odds ratios to provide an estimate of the relative risk of myocardial infarction associated with the ACE $D D$ genotype in groups of subjects with different $A G T_{1} R$ genotypes. The analyses were carried out by means of logistic regression models adjusted for age and population. Heterogeneity of odds ratios between $A G T_{1} R$ genotypes was tested by introducing corresponding interaction terms in the model. Tests for linear trend were done with the

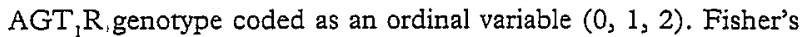
test was used for sets with small numbers.

\section{Results}

The $A G T_{1} R$ genotype distributions were compatible with Hardy-Weinberg expectations, except among cases in Strasbourg and controls in Lille, where there were fewer homozygotes than would be expected ( $p<0.05$, table 1 ). The genotype and allele frequencies of the $A G T_{1} R$ polymorphism did not differ between cases and controls (table 1), except in Strasbourg where the frequency of allele $C$ was significantly higher in cases $(p<0.05)$.

We found a significant interaction $(p<0.05)$ between $A C E$ and $A G T_{1} R$ gene polymorphisms on the risk of myocardial infarction. The association between the ACE $D D$ genotype and myocardial infarction was restricted to subjects carrying the $A G T_{1} R C$ allele, with a pronounced allele dose-effect. In the total population, the odds ratio (which approximates to the relative risk) for myocardial infarction associated with $A C E D D$ genotype varied from $1.05(0.75-1.49$, not significant) in subjects without the $\mathrm{AGT}_{1} \mathrm{R} C$ allele ( $A A$ homozygotes) to $1.52(1.06-2.18$, $\mathrm{p}=0.02)$ in $A C$ heterozygotes and 3.95 (1.26-12.4, $\mathrm{p}=0.02$ ) in $C C$ homozygotes (test for linear trend $\mathrm{p}<0.02$, table 2). Within each $A G T_{1} R$ genotype, the association was homogeneous across the study subpopulations.

$$
-
$$




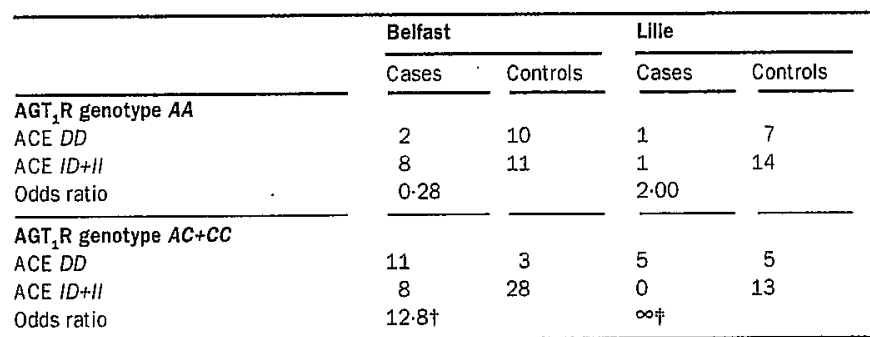

\begin{tabular}{|c|c|c|c|}
\hline \multicolumn{2}{|c|}{ Strasbourg } & \multicolumn{2}{|c|}{ Toulouse } \\
\hline Cases & Controls & Cases & Controls \\
\hline A & 5 & 6 & 8 \\
\hline 7 & 15 & 6 & 28 \\
\hline 1.71 & & 3.50 & \\
\hline 6 & 2 & 4 & 7 \\
\hline 7 & 10 & 5 & 19 \\
\hline 4.29 & & $2 \cdot 17$ & \\
\hline
\end{tabular}

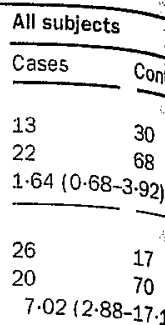

*Adjusted for population and age. Fisher's test, $\nmid p<0.001, \neq p=0.007, \xi p<0.0001$

Table 3: Distribution of ACE genotypes in cases and controls of study subpopulations in low-risk group according to AGT $R$ genotype

Since the reported effect of the ACE polymorphism is especially strong in subjects at low risk according to traditional risk factors, the analysis was repeated in the two risk groups. ${ }^{1}$ In the high-risk group, the association between the ACE $D D$ genorype and myocardial infarction was apparent only in subjects homozygous for the AGT $R$ $C$ allele. In the low-risk group, the interaction was stronger than that in the whole population; the odds ratios for myocardial infarction associated with the ACE $D D$ genotype varied from $1.64(0.68-3.92$, not significant) in subjects without the $A G T_{1} R C$ allele to $7.03(2 \cdot 61-19 \cdot 0$, $\mathrm{p}<0.0001$ ) in $A C$ heterozygotes, and 13.3 (Fisher's test, $\mathrm{p}=0.05$ ) in $C C$ homozygotes (test for linear trend $\mathrm{p}=0.02$, table 2).

Because the interaction was so strong in the low-risk group, we investigated whether it was present in the lowrisk groups in the different subpopulations of the ECTIM study. Because there were small numbers of $\mathrm{AGT}_{1} \mathrm{R} C C$ homozygotes in each population, $A C$ heterozygotes and $C C$ homozygotes were pooled for this analysis. In three of the four subpopulations, the effect of the ACE DD genotype on the risk of myocardial infarction was substantially increased in low-risk carriers of the $A G T_{1} R$ $C$ allele (table 3, risk increase significant in two subpopulations). Despite fluctuations in the size of the odds ratios, no significant heterogeneity was detected across the subpopulations, and the combined odds ratio in carriers of the AGT $R C$ allele was estimated at 7.02 $(2 \cdot 88-17 \cdot 1, p<0 \cdot 0001)$. The analysis was repeated after exclusion of the Lille sample, because the estimated odds ratio in this population was infinity, but the association remained highly significant (odds ratio $5 \cdot 26$ [2.08-13.3], $p<0.001)$. The heterogeneity of odds ratios between $A G T_{1} R$ genotypes was significant $(p<0.02)$.

The association previously found ${ }^{2}$ between the ACE I/D polymorphism and a parental history of myocardial infarction in controls was re-examined in the light of these findings. The odds ratio associated with the ACE $D D$

\begin{tabular}{|c|c|c|c|c|}
\hline & \multicolumn{2}{|c|}{$\mathrm{AGT}_{1} \mathrm{R}$ genotype $A A$} & \multicolumn{2}{|c|}{$\mathrm{AGT}_{2} \mathrm{R}$ genotype $A C+C C$} \\
\hline & $\begin{array}{l}\text { Parental } \\
\text { history of } \mathrm{Ml}\end{array}$ & $\begin{array}{l}\text { No parental } \\
\text { history of } \mathrm{Ml}\end{array}$ & $\begin{array}{l}\text { Parental } \\
\text { history of } \mathrm{MI}\end{array}$ & $\begin{array}{l}\text { No parental } \\
\text { history of } \mathrm{MI}\end{array}$ \\
\hline \multicolumn{5}{|c|}{ ACE genotype } \\
\hline$D D$ & 16 & 91 & 15 & 73 \\
\hline ID. & 20 & 144 & 24 & 171 \\
\hline 11 & 6 & 58 & 5 & 63 \\
\hline \multicolumn{5}{|c|}{$\overline{\text { Odds ratio }(95 \% \mathrm{CI})^{*}}$} \\
\hline$D D / 11$ & \multicolumn{2}{|c|}{$2.22(0.78-6.30)$} & \multicolumn{2}{|c|}{$3.62(1.16-11.3) \dagger$} \\
\hline $10 / 11$ & \multicolumn{2}{|c|}{$1.81(0.66-4.96)$} & \multicolumn{2}{|c|}{$2.05(0.71-5.90)$} \\
\hline
\end{tabular}

*Adjusted for age and population. $\dagger p<0.03$.

Table 4: Distribution of ACE genotypes according to parental history of fatal myocardial infarction in controls by $A G T_{1} R$ genotype genotype was significant in subjects carrying the AGT $C$ allele (3.62 [1.16-11.3], p<0.03); it was higher thia that in non-carriers of the $A G T_{1} R C$ allele, although difference was not significant (table 4). However, we must emphasise that the dilution of genes between generations: at the two loci causes a large decrease in power compare with the direct case-control approach.

\section{Discussion}

These results suggest that the association between the $A C E D D$ genotype and myocardial infarction is restricted to a subset of individuals, also carriers of the $A G T_{1} R^{11666}$ C allele. Moreover, the relative risk associated with the $\mathrm{AEE}$ $D D$ genotype seems to increase with the number of $A G T_{1} R C$ alleles, although we could not test this ideas each subpopulation because of small sample sizes. From the allele frequencies in the control population, we can estimate that $15 \%$ of individuals simultaneously carry the ACE DD genotype and the AGT, R C allele and $2.5 \%$ are double homozygotes. Our findings suggest that the AGE $D D$ genotype has a substantial impact, in terms of relative risk for myocardial infarction, in this particular subset of individuals.

Among controls in the high-risk group, there wasta significant deficit of subjects simultaneously homozygous for the ACE $D$ and AGT, R $C$ alleles (2 observed vs 107 expected, $\mathrm{p}<0.01$ ) and the deficit was apparent in all four subpopulations. Although purely speculative, one interpretation of this finding is that the combination of the ACE $D D$ and $A G T_{1} R C C$ genotypes, coupled with other risk factors, confers such a high risk of myocardial infarction that most of these individuals would have already sustained infarctions and possibly died from the disorder. The hypothesis of selection by death has been suggested previously. ${ }^{2.3,9}$

We have lately reported an excess of the $A G T_{1} R$ \% allele in severely hypertensive compared with normotensive subjects, which suggests involvement of the $A G T_{1} R$ gene in the predisposition to hypertension. ${ }^{24}$ In this study, however, we did not find any significant association between the AGT,R polymorphism and high blood pressure in the whole population.

The biological mechanism by which the ACE and $A G T_{1} R$ genes interact on the risk of myocardial infarction is unknown, but our findings suggest a possible epistatc effect of the two genes. Whereas the association of the ACE $D$ allele with increased expression of ACE is well known, no intermediate phenotype associated with the $A G T_{1} R C$ allele has been identified. Since the $A G T R$ gene polymorphism does not seem to be independently and directly associated with myocardial infarction, but modulates the relative risk conferred by the ACE $D$ allele we propose that the AGT $R C$ allele is associated withis 
dified response of, the receptor to angiotensin II. G-protein-coupled receptors, including the

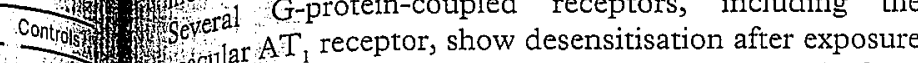
30 1. Whenomon can result from 68 . Wechanisms, including receptor protein

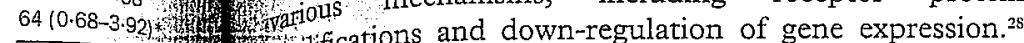
W 17 J6) modifying the encoded aminoacid

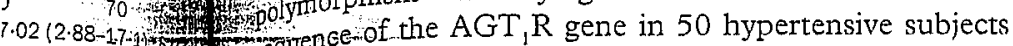

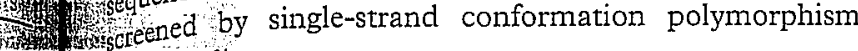

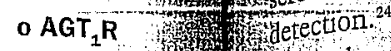

We therefore speculate that the $A G T_{1} R C$ allele is in ge disequilibrium with a functional variant that could ring the $\mathrm{AG}$ G was highen le, althorthat

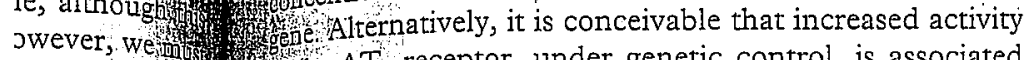
een generther jower comblon el $A T_{1}$ receptor blockade induces decreased plasma tissue $A C E$ activities. ${ }^{29}$ Since the ${ }_{\text {. }} \mathrm{AT}_{1}$. receptor and
$\mathrm{y}$. Wocardium, we also speculate that the gene variants ill interact through a local paracrine mechanism, since E E is a non-limiting step for angiotensin II generation tis lasma?

These results, if confirmed, could have clinical Wictions for the prevention and treatment of coronary disease. Screening for a genetic risk factor becomes th while if the factor is not uncommon and imparts a Helative risk, and if its detrimental effects can be unteracted pharmacologically or by other means. Since ow werful drugs, such as $A C E$ inhibitors and $A T_{1}$ receptor tagonists are available, it would be justifiable to donnider a clinical trial in patients at high risk of myocardial infarction and carrying the ACE DD genotype nd the AGT $R$ R allele.

ip, there w sly homozygo bserved $v \mathrm{~s}_{\mathrm{s}}$ sarent in allifit ieculative, combination s, coupleds ik of myocid als would y died rom death has

the $\mathrm{AGT}$ ompared rolvement to rpertension; any signifin phism and ossible epis sociation 0 of $\mathrm{ACE}$ is ciated Witi ace the $A$
$=$ independ infarction Le $A C E D$ ssociated opurwig EH, Comeli PS, Anderson JL, Marshall HW, Lalouel JM, Watd RH The ACE insertion/deletion polymorphism is independently mithistenosis. Girculation 1993; 88 (suppl): I-364.

6ripuiz $\mathrm{J}$, Blanché $\mathrm{H}$, Cohen $\mathrm{N}$, et al. Insertion/deletion polymorphism of the angiotensin-converting enzyme gene is strongly associated with coronary heart disease in non-insulin-dependent diabetes mellitus. Proc Natl Acad Sci USA 1994; 91: 3662-65.

Tho 1 , Berge KE, Bakken A, Erikssen J, Berg K. Insertion/deletion thom
(I/D) polymorphism at the locus for angiotensin I-converting enzyme and parental history of myocardial infarction. Clin Genet 1993; 44: 298-301.

8 Zhao Y, Higashimori K, Higaki J, et al. Significance of the deletion polymorphism of the angiotensin-converting enzyme gene as a risk factor for myocardial infarction in Japanese. Hypertens Res 1994; 17: 55-57.

9 Bohn $M$, Berge KE, Bakken A, Erikssen J, Berg K. Insertion/deletion (I/D) polymorphism at the locus for angiorensin I-converting enzyme and myocardial infarction. Clin Gent 1993; 44: 292-97.

10 Kreutz $T$, Lindpaintner $K$, Pfeffer $M A$, et al. Angiotensin-converting enzyme genotype and risk for coronary heart disease. Circulation 1993; 88 (suppl): $1-510$.

11 Shunkert H, Hense HW, Holmer SR, et al. Association berween a deletion polymorphism of the angiotensin-converting enzyme gene and left ventricular hypertrophy. $N$ Engl I Med 1994; 330: 1634-38.

12 Raynolds MV, Bristow MR, Bush EW, et al. Angiotensin-converting enzyme DD genotype in patients with ischaemic or idiopathic dilated cardiomyopathy. Lancet 1993; 342: 1073-75.

13 Marian AJ, Yu Q, Workman R, Greve G, Roberts R. Angiotensinconverting enzyme polymorphism in hypertrophic cardiomyopathy and sudden cardiac death. Lancet 1993; 342: 1085-86.

14 Bonithon-Kopp C, Ducimetière P, Touboul PJ, et al. Plasma angiotensin-converting enzyme activity and carotid wall thickening. Circulation 1994; 89: 952-54.

15 Rigat B, Hubert C, Alhenc-Gelas F, Cambien F, Corvol P, Soubrier F. An insertion/deletion polymorphism in the angiotensin I-converting enzyme gene accounting for half the variance. of serum enzyme levels. 7 Clin Invest 1990; 86: 1343-46.

16 Costerousse O, Allegrini J, Lopez M, Alhenc-Gelas F. Angiotensin Iconverting enzyme in the human circulating mononuclear cells: genetic polymorphism of expression in T lymphocytes. Biochem $\mathcal{F}$ 1993; 290: 33-40.

17 Tiret L, Rigat B, Visvikis $S$, et al. Evidence, from combined segregation and linkage analysis, that a variant of the angiotensin I-converting enzyme (ACE) gene controls plasma ACE levels. An f Hum Genet 1992; 51: $197-205$

18 Timmermans PBMWM, Wong PC, Chiu AT, et al. Angiotensin II receptors and angiotensin II receptor antagonists. Pharnacol Rev 1993; 45: 205-25.

19 Geisterfér A, Peach MJ, Owens GK. Angiotensin II induces hypertrophy, not hyperplasia of cultured rat aortic smooth muscle cells. Circ Res 1988; 62: 749-56.

20 Daemen MJAP, Lombardi DM, Bosman FT, Schwartz SM. Angiocensin II induces smooth muscle cell proliferation in the normal and injured rat arterial wall. Circ Res 1991; 68: 450-56.

21 Chiu AT, Herblin WF, MCCall DE, et al. Identification of angiotensin II receptor subtypes. Biochen Bioplyys Res Conmun 1989; 165: 196-203.

22 Paxton WG, Runge M, Horaist C, Cohen C, Alexander RW, Bernstein IKE. Immunohistochemical localization of rat angiotensin II AT1 receptor. Am $\mathcal{F}$ Physiol 1993; 264: F989-95.

23 Takayanagi R, Ohnaka K, Sakai Y, et al. Molecular cloning, sequence analysis and expression of a cDNA encoding human type-1 angiotensin II receptor. Biochem Biophys Res Commun 1992; 183: 910-16.

24 Bonnardeaux A, Davies $E$, Jeunemaitre $X$, et al. Angiotensin II type 1 receptor gene polymorphisms in human essential hypertension. Hypertension 1994; 24: 63-69.

25 Parra HJ, Arveiler D; Evans AE, et al. A case-control study of lipoprotein particles in two populations at contrasting risk for coronary heart disease: the ECTIM Study. Atterioscler Thromb 1992; 12: 701-07.

$26 \mathrm{Kee} F$, Tiret L, Robo JY, et al. Reliability of reported family history of myocardial infarction. $B M F$ 1993; 307: 1528-30.

27 Rigat B, Hubert C, Corvol P, Soubrier F. PCR detection of the insertion/deletion polymorphism of the human angiotensin-converting enzyme gene (DCP 1) (dipeptidyl carboxypeptidase 1). Nucl Acids Res 1992; 20: 1433

28 Collins S, Caron MG, Lefkowitz RJ. From ligand binding to gene expression: new insight into the regulation of $\mathrm{G}$-protein-coupled receptors. TIBS 1992; 17: 37-39.

29 Scheiffer B, Wirger A, Meybrunn M, et al. Comparative effects of chronic angiotensin-converting enzyme inhibition and angiotensin II type 1 receptor blockade on cardiac remodeling after myocardial infarction in the rat. Circulation 1994; 89: 2273-82.

30 Danser AHJ, Koning MMG, Admiraal PJJ, Derkx FHM, Verdouw PD, Schalekamp MADH. Metabolism of angiotensin I by different tissues in the intact animal. Am $\mathcal{F}$ Physiol 1992; 263: H418-28. 